\title{
Review on Camel Pox: Epidemiology, Public Health and Diagnosis
}

\author{
Diriba Achalu Bayisa \\ College of Veterinary Medicine Department of Veterinary Medicine Olana Merera, Dvm, Msc, Assist. Prof \\ *Corresponding Author: Diriba Achalu Bayisa, College of Veterinary Medicine Department of \\ Veterinary Medicine Olana Merera, Dvm, Msc, Assist.Prof, Email: Diree.achalu@gmail.com
}

\begin{abstract}
A Camelus dromedary is an essential livestock species distinctively adapted to hot and arid environment. In Ethiopia, they contribute very constructively to the food security of pastoralist households. In spite of this contribution camels are found to be affected by a large number of bacterial and viral diseases. Camel pox is one of the most important infectious and contagious viral diseases of camels in almost every region where the camel is reared. The disease is caused by the Camel pox virus, which belongs to the Orthopox virus genus of the pox viridae family. Camel pox has a considerable economic importance due to high morbidity, relatively high mortality in younger animals, loss of body condition and reduced milk production in lactating ones. The disease is transmitted through direct contact, indirect contact, and insect vectors. The clinical manifestations range from in apparent infection to mild, moderate, and less commonly severe systemic infection and death. The disease is characterized by fever, enlarged lymph nodes and skin lesions. Young calves and pregnant females are more susceptible. Tentative diagnosis of Camel pox can be made based on clinical signs and pox lesion, but it may confuse with other viral diseases like contagious ecthyma and papillomatosis. Therefore, confirmatory tests are needed. The routine laboratory techniques which are commonly done for Camel pox diagnosis are transmission electron microscopy, cell culture isolation, standard polymerase chain reaction assays, immunohistochemistry and demonstration of neutralizing antibodies. Treatment is often directed to minimizing secondary infections by topical application or parenteral administration of broad-spectrum antibiotics and vitamins. It can be controlled or prevented by vaccination. When inactivated vaccine is used in endemic area the animals must be vaccinated annually. The objective of this paper review on Camel pox was to review available information's on the epidemiology and diagnostic techniques and overview on its public health significances and economic importance. In addition, priority should also be given to researches that help in deepening the understanding of epidemiology of the disease and developing assay, rapid, and accurate diagnostic technique should be needed that can be used at field condition.
\end{abstract}

Keywords: Camel pox, Epidemiology, Diagnosis

Abbreviations: AI: Inactivated Adjuvant, BP:Base Pairs BPXV: Buffalo pox Virus, CAM: Chorio allantoic Membrane, CFR: Crude Fatality Rate, CMLV: Camel pox Virus, CPXV: Capri pox Virus, ELISA: Enzyme Linked Immunosorbant Assay, FAO: Food and Agricultural Organization, HA: Hem agglutination, MW: Molecular Weight, OIE: Office International Des Epizootis, OPV: Ortho pox Virus, PCR: Polymerase Chain Reaction, PCV: Packed Cell Volume, RBC: Red Blood Cell, REA: Restriction Enzyme Analysis, TEM: Transmission Electron Microscope, VACV: Vaccinia Virus, VARV: Variola Virus, WBC: White Blood cell

\section{INTRODUCTION}

There are approximately 20 million camels in the world of which 15 million in Africa and 5 million in Asia (GLIPHA, 2006). In 2001 the total camel population was 19 million of which 17 million were dromedaries (Camel dromedaries, one humped) and 2 million were Bactrian camels (Camel bactrianus, two humped camel) (Farah et al, 2004). Ethiopia possesses over one million Camelus dromedaries mainly distributed in the Southern, Eastern and

ARC Journal of Animal and Veterinary Sciences
Northeast regions (CSA, 2008).

Camels are the most capable animal species in utilizing marginal areas and in survival and production under harsh environmental conditions (Schwartz and Dioli, 1992). It is a symbol of human survival in the desert forming the core of culture and agriculture of the hot dry areas of northern hemisphere (FAO, 2001). As the world expects increased global warming, the camel would perhaps be the most favored animal to develop (Ahmad et al., 2010). Many 
pastoral groups and communities in diverse ecological zones throughout the world are depending on camels for their livelihood. This dependence consists of utilization of camel meat, milk, leather and wool, exportation of live camels, uses as an important sport and tourism resource in the Arabian Gulf countries and lastly the use of camels as animals for packing, transport and riding (Snow et al., 1992).

Ethiopia has one of the largest camel populations in the world, in which they are kept in arid lowlands, which cover $50 \%$ of the country and home range for over 2 million pastoralists (Getahun and Bruckner, 2000). The most significant merit to perform in areas where other livestock species do not thrive and perhaps do not survive are attributed to the economic use of water in almost all metabolic functions and wide range of feed resource utilization. In mixed species the camel feeds on plants and parts of plants that are not eaten by other conventional livestock due to its size to browse the highest strata, thus reducing competitions and enhancing complementariness. However, these potential merits of camel have not fully exploited because of pathological limitation (Wilson, 1998).

Camel pox was initially described in Punjab, India, in 1909. Subsequently, outbreaks have been reported in many countries of the Middle East, Asia, Africa and southern Russia, where the disease is enzootic. Of note, Camel pox has never been reported in Australia,

even though camel farming is practiced (Wernery and Kaaden, 2002). Camel pox is one of the most important infectious and contagious diseases of camels in almost every region where the camel is reared with the exception of Australia. The disease is caused by the Camel pox virus (CMLV), which belongs to the Ortho pox virus (OPV) genus of the pox viridae family (Gubser and Smith, 2002; OIE, 2008; Duraffour et al., 2011). Approximately 25\% of young camels that become infected will die from the disease, while infection in older camels is generally milder (Fenner et al., 1993). Although rare, the infection may spread to the hands of those that work closely with camels (Carter and Wise, 2006). Camel pox has a considerable economic importance due to high morbidity, relatively high mortality in younger animals, loss of condition and reduced milk production in lactating ones (Azwai et al., 1996).

Camels were formerly considered resistant to most of the disease commonly affecting livestock (Dalling et al., 1988), but as more research was conducted camels were found to be susceptible to a large number of pathogenic agents. Outbreaks have been reported in the Middle East, in Asia, Africa and in the southern parts of Russia and India. The disease is endemic in these countries and a pattern of sporadic outbreaks occurs with a rise in the seasonal incidence usually during the rainy season (Mayer and Czerny, 1990; Werney et al., 1997). Even though a handful studies were conducted on Camel pox in Ethiopia, the occurrence of the disease is frequently reported by field veterinarians and camel herders in different camel rearing areas of the country; indicating that it requires frequent epidemiological investigation with appropriate diagnostic method. Therefore, the objective of this seminar paper is:-

- To review Camel pox with particular emphasis on its epidemiology and diagnosis.

- To give overview on zoonotic importance's and economic importance.

\section{LITERATURE REVIEW}

\subsection{Etiology}

The Camel pox virus that causes Camel pox is an Orthopoxivirus virus that is very closely related to the Vaccinia virus that causes Small pox. It is a large, brick-shaped, enveloped virus that ranges in size from $265-295 \mathrm{~nm}$. The viral genetic material is contained in double stranded linear DNA consisting of 202,182 tightly packed base pairs. The DNA is encased in the viral core. Two lateral bodies are found outside the viral core, and are believed to hold the enzymes required for viral reproduction (Gubser et al., 2001). The Camel pox virus most often affects members of family Camelidae. However, recent studies show that the disease can be transmitted to both humans and arthropods (Jezek et al., 1983).

\subsection{Physicochemical Properties}

Camel pox virus, like other OPVs, shows variable responses to physical and chemical agents. In general, Camel pox virus is ether resistant and chloroform sensitive. The virus is sensitive to $\mathrm{pH}$ 3-5 and $\mathrm{pH}$ 8.5-10. However, Etha 78 strain of Iraq is resistant to both ether and chloroform whereas the $\mathrm{Cp} / \mathrm{Nw} / 92 / 2$ isolate of Sudan is sensitive to both agents (Khalafalla et al., 1998). Pox viruses are susceptible to various disinfectants including $1 \%$ sodium hypochlorite, $1 \%$ sodium hydroxide, $1 \%$ per 
acetic acid, formaldehyde, $0.5-1 \%$ formalin and $0.5 \%$ quaternary ammonium compounds. The virus can be destroyed by autoclaving, boiling for 10 minutes and is killed by ultraviolet rays (245 nm wave length) in a few minutes. CMLV (H 520 strain of Kenya) hemagglutinates red blood cells of cockerel. However, the CMLV Etha 78 strain agglutinates chicken RBCs at room temperature with a $\mathrm{pH}$ range of 6-8 (Coetzer, 2004).

\subsection{Morphology}

Camel pox is a large, brick-shaped, enveloped virus that ranges in size from $265-295 \mathrm{~nm}$. The viral genetic material is contained in double stranded linear DNA consisting of 202,182 tightly packed base pairs. The outer envelope consists of a lipoprotein layer embedding surface tubules and enclosing a core described as biconcave because of an electron microscopy fixation artifact. The core contains the viral DNA and core fibrils, and it is surrounded by the core envelope and a tightly arranged layer of rod-shaped structures known as the palisade layer. Between the palisade layer and the outer envelope are two oval masses known as the lateral bodies (Gubser et al., 2001).

\subsection{Replication}

The Ortho pox virus that causes Camel pox behaves very similarly to the virus that causes Small pox. After the virus attaches to a host cell, it injects its viral core (the shell containing its DNA) into the cell's cytoplasm. The virus carries DNA polymerase which is used to transcribe its genes. Eventually, the viral core dissolves, and the genetic material is bear within the cytoplasm. When all of the structural proteins have been produced, viral assembly takes place. The newly formed virus particles can be released during cell lysis, or they can derive a host cell produced membrane and be released via budding (Gubser et al., 2001).

\section{EPIDEMIOLOGY}

\subsection{Susceptible Host}

VARV and CMLV are restricted to a single host, humans for VARV and camels for CMLV, in which they induce a severe disease, while other OPVs can infect various hosts, including rodents, zoo animals, monkeys and humans. Old World (dromedary and Bactrian) camelids have been recognized as the reservoir hosts of CMLV, although New World camelids, such as guanacos, may be experimentally infected. And also, arthropod vectors involved in the transmission of the disease could be infected (Wernery and Zachariah, 1999). In general, strains of CMLV have an extremely limited host range. Intra-dermal inoculation of the virus into sheep, goats, rabbits, guinea pigs, rat, hamsters and mice have not been successful (Bhanuprakash et al., 2010). Apart from camels, the only animals that have been infected successfully are monkeys and infant mice. Even in natural infection, sheep and cows that were in direct contact with infected camels were healthy indicating that CMLV is mostly host specific (Al-Ziabi et al., 2007). However, CP/Nw/92/2 isolates of CMLV in Sudan were able to produce local pox lesions in chicken (Khalafalla, 1998).

\subsection{Mode of Transmission}

Risk factors associated with higher incidence of Camel pox have been defined and include the average age of the animals (less than four years old), the rainy season of the year, the introduction of new camels in a herd and the common watering. Transmission of Camel pox occurs by direct contacts with sick animals through skin abrasions or via aerosols. Scab materials, saliva and secretions of affected camels may shed virus in the environment, such as in water which becomes then the source of infection (Wernery and Kaaden, 2002; Khalafalla and Ali, 2007). Various studies have demonstrated that the incidence of Camel pox outbreaks increased during rainy seasons with the appearance of more severe forms of the disease, while during the dry season milder forms are seen. It is hypothesized that CMLV strains of different virulence may explain the differences in

pathogenicity seen between dry and wet seasons, but this has never been assessed. Another possibility could be the involvement of arthropod populations which, abundant during rainy seasons, may exert a greater virus pressure onto camel populations. This idea is supported by the isolation of CMLV from Hyalomma dromedarii ticks. During an outbreak of Camel pox in United Arab Emirates in 1995-1996, twenty ticks were collected from five camels with generalized camel pox. Ticks, processed for electron microscopic and cell culture analyses, were found to contain CMLV. However, the question remains whether ticks might transmit CMLV mechanically or whether they might be a true reservoir of the virus. In the last case, the maintenance and spread of Camel pox would be explained by transtadial transmission (the pathogen is maintained in the 
vector from one developmental stage to subsequent stages) or transovarial transmission (Wernery et al., 1997; Khalafalla and Ali, 2007).

\subsection{Morbidity and Mortality Rate}

The morbidity rate of Camel pox is variable and depends on whether the virus is circulating in the herd. Serological surveys taken in several countries reveal a high prevalence of antibodies to Camel pox (Werney and Kaaden, 2002). The incidence of disease is higher in males than females, and the mortality rate is greater in young animals than in adults. The mortality rate in adult animals is between 5\% and 28\% and in young animals between 25\% and 100\% (Mayer and Czerny, 1990). Furthermore, the mortality is influenced by the presence of inter-current diseases (notably trypanosomiasis), stress, age, and the nutritional status of the animal and virus virulence (Al Hendi et al., 1994). Camel pox outbreaks are often temporal due to the movement of camels for grazing and watering, which results in mixing of the herds and the introduction of new camels into a herd (Azwai et al., 1996). In most herds, the infection is frequently seen in the young camel crop as the acquired maternal immunity wanes after 5-8 months after birth (Nothelfer et al., 1995).

\subsection{Predisposing Factor}

Various studies have demonstrated that the incidence of Camel pox outbreaks increases during rainy seasons with the appearance of more severe forms of the disease (Wernery et al., 1997; Khalafalla and Ali, 2007). This may be due to the fact that moisture may enhance virus stability in the environment and increase subsequent transmission to susceptible animal. It could be also associated with the involvement of arthropods which are abundant during rainy seasons which may serve as a mechanical vector of the virus. The latter idea is evidenced by the isolation of CMLV from Hyalomma dromedarii ticks (Wernery and Zachariah, 1999; Wernery et al., 2000).The outbreak in a herd is very often associated with weaning or poor nutrition, with fatal severe form occasionally. Disease occurrence is accompanied with morbidity, mortality, and case fatality rates respectively of $30-90 \%, 1-15 \%$, and $25 \%$ (Al-Ziabi et al., 2007).

\subsection{Geographical Distribution of Camel pox}

The disease is endemic in these countries and a pattern of sporadic outbreaks occurs with a rise in the seasonal incidence usually during the rainy season (Mayer and Czerny, 1990; Werney et al., 1997). Even though the occurrence of Camel pox in Ethiopia is frequently reported by field veterinarians and camel herders; the epidemiology of the disease is not well studied. There are only two studies in Ethiopia, one was reported from the Borena area on occurrence of seasonal variations; $14.2 \%, 0.3 \%$ and $0 \%$ prevalence during minor wet, major wet and dry seasons respectively (Megerssa, 2010). Another report was higher than $0.45 \%$ in Afar and Eastern Amhara Region in which out of 1100 camels examined only five camels showed typical sign of Camel pox reported by (Demeke, 2002).

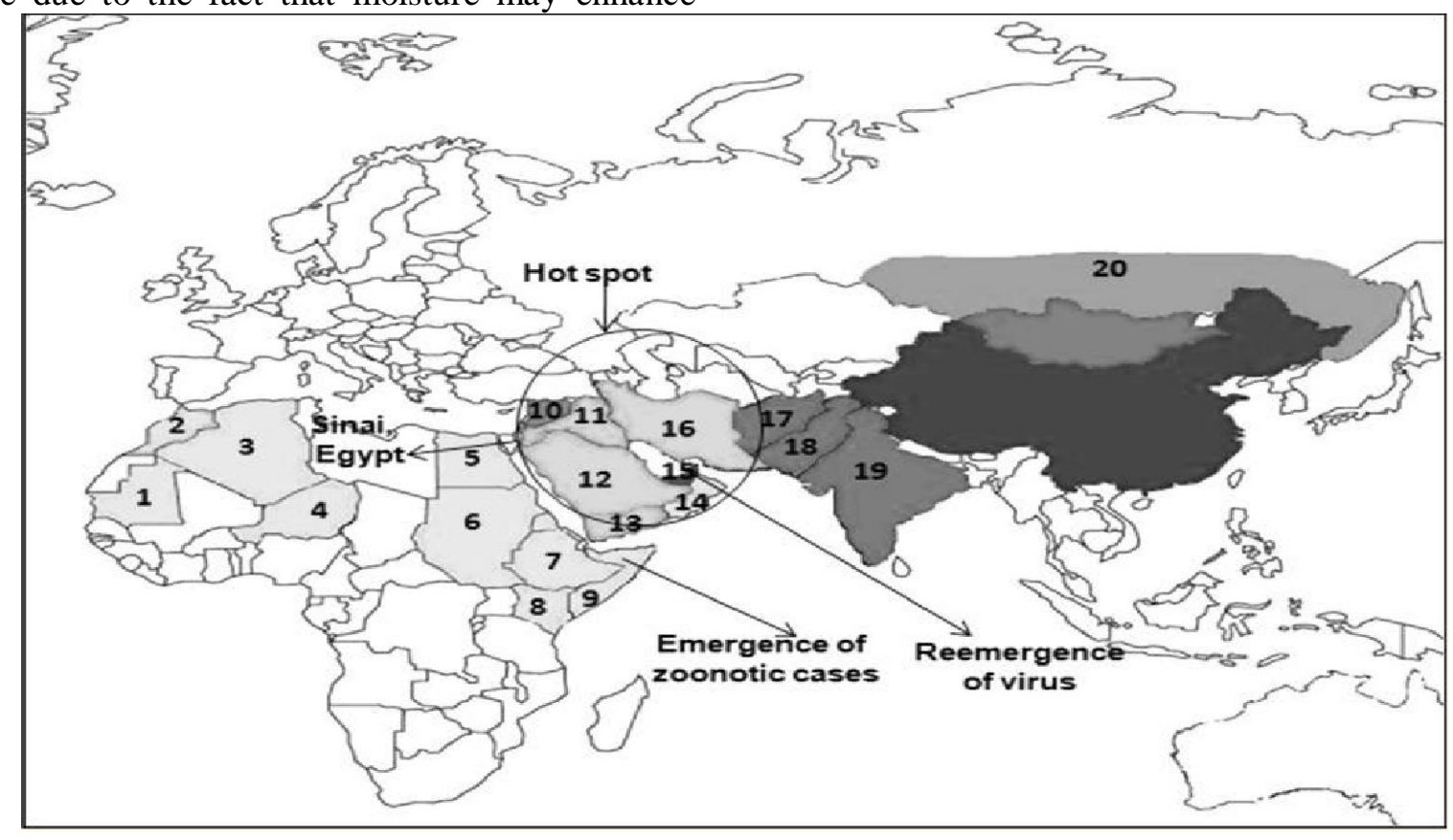

Figure1: Global distribution of camel pox Source: Mayer and Czerny, (1990) 


\subsection{Pathogenesis}

The incubation period varies from 4 to 15 days with an initial rise in temperature followed by papules on labia, vesicles, pustules, and finally formation of scabs. Skin lesions appear 1-3 days after the onset of fever, starting as erythematous macules, developing into papules and vesicles, and later turning into pustules. Crusts develop on the ruptured pustules. These lesions first appear on the head, eyelids, nostrils and the margins of the ears. In severe cases the whole head may be swollen. Later, skin lesions may extend to the neck, limbs, genitalia, mammary glands and perineum (Werney and Kaaden, 2002).

\subsection{Clinical Manifestation}

Clinical manifestations of Camel pox range from inapparent and mild local infections, confined to the skin, to moderate and severe systemic infections, possibly reflecting differences between the strains of Camel pox .The disease is characterized by fever, enlarged lymph nodes and skin lesions. In the generalized form, pox lesions may cover the entire body. Skin lesions may take up to 4-6 weeks to heal. In the systemic form of the disease, pox lesions can be found in the mucous membranes of the mouth, respiratory and digestive tracts (Werney and Kaaden, 2002).

In most cases, CMLV infection was reported to be relatively benign, especially in adult camels. However, severe infections with a high CFR and blindness are common in young camels, while abortions, still birth, weight loss and reduced milk yield may be seen in adult animals (Higgin et al., 1992; Nothelfer et al., 1995). The animals may show salivation, systemic form of the disease. Pregnant females may abort. Death is usually due to septicemia caused by secondary bacterial infections such as Staphylococcus aureus (Wernery and Kaaden, 2002).

\subsection{Postmortem Lesions}

There is limited information on the pathology of camel pox. The lesions observed on postmortem examination of camels that die of severe Camel pox infection are multiple pox-like lesions on the mucous membranes of the mouth, respiratory (mainly on the trachea and lungs) and digestive tracts. The size of the lesions in the lungs may vary between 0.5 and $1.3 \mathrm{~cm}$ in diameter and occasionally may reach up to 4-5 $\mathrm{cm}$ in diameter. Smaller lesions may have foci of hemorrhagic center on the surface of the lungs. In addition, infection of the heart and liver has also been observed in fatal forms of Camel pox infection (Pfeffer et al., 1998).

\subsection{Treatment}

Camel pox virus is one of the viruses closely related to VARV. Post-exposure treatment of Camel pox infection has also not yet been described. Treatment of severe cases includes minimization of secondary infections by topical application or parenteral administration of broad-spectrum antibiotics and vitamins (Wernery and Kaaden, 2002). Alternative treatments include the use of antiviral agents such as cidofovir and ST-246. Cidofovir inhibits CMV and pox virus DNA polymerase (Xiaong et al., 1996; Duraffour et al., 2007; Sliva and Schnierle, 2007). It is effective against DNA viruses particularly papillomaviruses, polyomaviruses, adenoviruses, herpesviruses and pox viruses. Among the pox viruses it is effective against VARV, VACV, CPXV, CMLV and MPXV. The antiviral activity is long-lasting owing to the long half-life of its metabolites. Some of the derivatives of cidofovir have oral bioavailability. In some cases, resistant viruses are difficult to treat with cidofovir but their virulence can be attenuated (Smee et al., 2002).

ST-246 is a novel, low molecular weight, potent, orally bioavailable and selective compound against several OPVs including VACV, ectromelia, CPXV, CMLV, MPXV and VARV (Yang et al., 2005; Berhanu et al., 2009). ST-246 is readily absorbed following oral administration with mean times to maximum concentration from 2 to 3 hours. Absorption of the compound is greater in no fasting humans than fasting humans (Jordan et al., 2008). Furthermore, ST-246 administered in combination with small pox vaccine does not interfere with vaccine-induced protective immunity, which is indicated by the appearance of takes at the site of inoculation of the vaccine and protection of vaccinated animal against virulent challenge (Grosenbach et al., 2008). Likewise, combined administration of ST-246 and CMX001 (hexadecyloxypropyl-cidofovir) exhibits synergistic effects in vitro against VACV and CPXV and in vivo against CPXV. Taken together, some of these compounds have good chemoprophylactic or chemotherapeutic potential in treating not only OPXVs in general but also CMLV in particular (Quenelle et al., 2007).

\subsection{Control and Prevention}

Camel pox can be controlled or prevented by vaccination. Currently there are two types of 
vaccines, live attenuated and inactivated Camel pox vaccines. A live attenuated vaccine gives long-term protection against camel pox. However, a booster vaccination is recommended for young animals vaccinated before the age of 6-9 months. When inactivated vaccine is used, the animals must be vaccinated annually (Wernery and Zachariah, 1999; Wernery, 2000; OIE, 2008). The ability to confirm a clinical diagnosis of Camel pox through rapid molecular testing would be of critical importance in efforts to control and eradicate the disease. Since Camel pox affects only camel, its causative agent has no wildlife reservoir and availability of diagnostic tests and vaccines to diagnose the disease and block its transmission; Camel pox meets the basic requirements to be a candidate for eradication (Aylward, et al., 2000). The Camel pox virus is sensitive to a number of common disinfectants. It can also be destroyed by autoclaving, short term exposure to UV light, and boiling for at least 10 minutes. These methods may be used by camel herders to minimize risk of environmental contamination just like small pox in humans; the disease could be eliminated by isolating sick camels and vaccinating the rest, using either the traditional vaccinia virus vaccine or a more recently developed Camel pox virus vaccine (Bray and Babiuk, 2011).

\subsection{Immunity to Infection and Vaccination}

Immunity against Camel pox is dependent on both humoral and cell-mediated immune responses, although the circulating antibodies do not reflect the immune status of the animal (OIE, 2008). Camel pox infections produce long-lasting immunity in recovered animals. Live-attenuated vaccine provides protection for at least 6 years whereas inactivated vaccine provides only 1 year of protection and demanding a booster after 8 weeks (Wernery and Zachariah, 1999). Among the two commercially available Camel pox vaccines, namely Duca pox live- attenuated vaccine from South Africa and an inactivated adjuvant (IA) vaccine from Morocco, the immune response in terms of antibody for both vaccines (serum neutralization and passive hemagglutination tests) was observed in the second week postvaccination and a booster dose enhances the antibody titers significantly. However, the IA vaccine induces only low antibody levels. All camels vaccinated with both vaccines react positively and produce delayed-type hypersensitivity reaction, with a remarkable increase in skin thickness as compared with controls, indicating a pronounced cell-mediated immune response. The increase in thickness was relatively greater with the live-attenuated compared with the IA vaccine. Field vaccination trials showed that both vaccines induce a weak immune response in camels less than 6 months of age and older than 4 years. This is attributed to the possible presence of maternal antibodies or the under-development of the immune system in camel calves and the occurrence of prevaccination antibodies in adult camels. Good immune responses were observed in 1-4-yearold camels as measured by serological tests, namely PHA which is easy, sensitive and economical compared with serum neutralization. Both vaccines were found to be safe, potent and immunogenic as they induced humoral and cellular immune responses, and protected vaccinated dromedaries after challenge. The appropriate age for vaccination with both vaccines is 6 months (Khalafalla and El Dirdiri, 2003).

\section{DAignosis}

The presumptive diagnosis of Camel pox infection can be made on the basis of clinical signs. However, infections of camels in the early clinical stages and in mild cases should be differentiated from contagious ecthyma (Orf), which is caused by a para pox virus (PPV), papillomavirus infections and insect bites. Several diagnostic methods are available for the diagnosis of Camel pox (Pfeffer et al., 1998), but it is preferred to use more than one test for confirmatory diagnosis.

CMLV has also been detected by isolation and transmission electron microscopy (TEM) of the camel tick, Hyalommadromedarii (OIE, 2008). Para pox viruses and papillomaviruses have also been associated with skin infections of camel similar to Camel pox lesions (Renner-Muller, 1995; Munz, 1997). Therefore, these infections cannot be differentiated solely on clinical signs. However, Camel pox is diagnosed based on clinical signs, epizootiological and pathological findings, virus isolation, electron microscopy and genus-specific antigen capture ELISA (Johann and Czerny, 1993; Al-Ziabi et al., 2007). Camel pox could be differentiated from other OPXV and PPV infections by the use of restriction enzyme analysis (REA) (Murphy et al., 1999). Recently, C18L gene based speciesspecific PCRs (in conventional and real-time formats) have been developed to differentiate CMLV from BPXV (a regional isolate of VACV) and other OPXVs (Balmurugan et al., 2009). 


\subsection{Transmission Electron Microscopy}

Transmission electron microscopy is a rapid method to demonstrate OPXV in scabs or tissue samples. The laboratory confirmation of Camel pox occurs through the demonstration of the characteristic brick-shaped ortho pox virions in skin lesions, scabs or tissue samples (Al-Ziabiet al., 2007). The virus is distinct from ovoidshaped PPV, the etiological agent of camel contagious ecthyma (Orf). High concentration of virus in the sample is required for positive diagnosis and it is not possible to differentiate CMLV from other OPXV species. However, TEM is currently the best method for distinguishing clinical cases of Camel pox and Orf caused by Camel pox and PPVs, respectively, although the viruses can be differentiated by serological and PCR assays (Mayer and Czerny, 1990).

\subsection{Immunohistochemistry}

Camel pox can be confirmed by immunohistochemical demonstration of the Camel pox antigen (OPXV fusion protein) in scabs and pox lesions in tissues (Nothelferet al., 1995). It is a fast method and can be used in lieu of TEM to establish a tentative diagnosis (Wernery and Kaaden, 2002). In addition, the paraffin-embedded samples can be stored for a long period, enabling future epidemiological and retrospective studies. Monoclonal and polyclonal antibodies can be used. However, almost any polyclonal antibody against VACV is likely to produce results in this test, as there is greater degree of similarity between VACV and CMLV (Nothelfer et al., 1995).

\subsection{Virus Isolation}

\subsubsection{Embryonated Chicken Eggs}

Camel pox virus can be isolated on the CAM of 11-13-day-old embryonated chicken eggs. The eggs should be incubated at $37^{\circ} \mathrm{C}$, and after 5 days characteristic dense, greyish white pock lesions are observed on the CAM. CMLV does not cause the death of inoculated embryonated chicken egg. The optimum Temperature for the formation of pock lesions is $38.5^{\circ} \mathrm{C}$. If the eggs are incubated at $34.5^{\circ} \mathrm{C}$, the pocks are flatter and a hemorrhagic center may develop (Tantawi et al., 1974) .Opaque white proliferative pock lesions of approximately $0.5-0.6 \mathrm{~mm}$ diameter were demonstrated on the CAM on the fifth day without any hemorrhagic lesions but with stunted growth (Chauhan and Kaushik, 1987; Marodam et al., 2006). Characteristic long, opaque, white proliferative pock lesions have been produced when Vero cell-adapted virus was inoculate onto CAM (Marodam et al., 2006).

\subsubsection{Cell Cultures}

Various cell lines are susceptible to CMLV including HeLa, GMK-AH1, BSC-1, WISH and Vero. CMLV can also be propagated in MA-104 and MS monkey kidney and baby hamster kidney cells. Primary cell cultures such as lamb testis, lamb kidney, camel embryonic kidney, calf kidney and chicken embryo fibroblast can also be used (Tantawi et al., 1974). CMLV shows typical cytopathic effects on a wide variety of cell cultures. Intra-cytoplasmic eosinophilic inclusion bodies, characteristic of pox virus infection, may be demonstrated in infected cells using hematoxylin and eosin staining. Pox viruses are epitheliotropic, and both VACV and CPXV have the ability to infect raft cultures of human keratinocytes. Interestingly, CMLV also has the ability to infect human keratinocytes even though the CMLV is restricted to camels. Unlike VACV or CPXV, which have wider host specificity, CMLV has also been shown to infect HEL fibroblasts. The changes in CMLV-infected rafts were cytopathic and are identical to those described for epithelium isolated from infected camels (Duraffou ret al., 2007). The characteristic cytopathic effect includes rounding, vacuolization, multinucleated giant cell formation, syncytia and cytolytic changes in Vero cells (Pfeffer et al., 1996; Marodom et al., 2006).

\subsection{Serological Tests}

A set of serological tests including haemagglutination (HA), haemagglutination inhibition, virus neutralization test (VNT), indirect ELISA, complement fixation, and fluorescent antibody tests/assays are available for the detection of antibody to CMLV (Balamurugan et al., 2013).VNT and ELISA are the most commonly used and sensitive tests. VNT test is based on a reaction between the virus and specific antibody in the test serum. Virus and products containing a neutralizing antibody were mixed under appropriate conditions and then inoculated into cell culture. The presence of unneutralized virus was detected by plaque formation (cytopathic effect). A loss of infectivity was caused by interference by the bound antibody with any of the steps leading to the release of the viral genome from the host cells including attachment, infection, or viral release. On the 
other hand, ELISA is developed for the detection of total IgG and IgM antibodies to camelpox virus in camel sera and for identifying the seroreactive antigens of the virus. It is a simple method which can successfully be applied for retrospective and also for epidemiological investigations. The test is more sensitive than virus neutralization (VNT) (Azwai et al., 1996).

\subsubsection{Serum Neutralization Test}

Neutralization is the most common and confirmatory test for the diagnosis of OPXV infections. Commonly, the test sera are titrated against a constant CMLV (OIE, 2008).

\subsubsection{Fluorescent Antibody Test}

Fluorescent antibody testing also determines the status of antibodies in camels infected with CMLV. Although, there has been crossfluorescence between virus and antisera of members of the OPXV group (including H 520 CMLV, VACV and CPXV), other related viruses such as capri pox, avi pox and PPVs show no cross-fluorescence in indirect fluorescent antibody test (Davies et al., 1975).

\subsubsection{Enzyme linked immunosorbent assay}

ELISA and Western blotting have been developed recently for the detection of $\mathrm{IgG}$ and IgM antibodies to CMLV in camel sera and OPXVs can be differentiated from PPV infections in camels (Azwai et al., 1996). As ELISA is simple, it can successfully be applied for retrospective and also for epidemiological investigations. The test is more sensitive than virus neutralization (VNT), HA inhibition, PHA and indirect fluorescent antibody tests for detecting antibodies to VACV and monkey pox virus (MPXV) (Marennikova et al., 1981). Furthermore, VNT used for the detection of OPXV infection do not measure antibodies to envelope antigens, which are the prime agents in CMLV pathogenesis. In such instances, specificity of a test is of major importance to differentiate OPXVs and PPVs, which are known to cause similar pox -like lesions in camels (Jezek et al., 1983; Munz et al., 1986). Likewise, $95 \%$ prevalence of Camel pox antibodies in camels from Kenya, Somalia and Sudan has been reported using ELISA, in which semi- purified CMLV antigen was, employed (Pfahler et al., 1986). Later, in order to increase the specificity of ELISA for CMLV, a purified CMLV was used in ELISA, which resulted in low background signal with the negative control camel sera. Therefore, like in other disease, use of purified antigen in CMLV-ELISA has to be employed (Azwai et al., 1996).

\subsubsection{Western Blot Analysis}

One step ahead of ELISA, Western blotting is applied for the confirmation of the specificity of the ELISA. When blotting pattern of MPXV, VACV, BPXV, CPXV and ectromelia viruses were compared, three characteristic bands of MW 23, 31 and $35 \mathrm{kDa}$ for CMLV were obtained and which enabled to differentiate CMLV from the above listed OPXVs(November et al.,1989). CMLV is identified from the VACV group by the absence of a $23 \mathrm{kDa}$ protein band and is distinguished from all others by possessing 31 and $35 \mathrm{kDa}$ protein bands. Although the $23 \mathrm{kDa}$ CMLV band has been found in other OPXVs, it is absent in MPXV (human, and monkey isolates). 31 and $35 \mathrm{kDa}$ proteins are present in all CMLV-positive camel sera (Azwai et al., 1996).

\subsubsection{Restriction Enzyme Profiling}

Restriction enzyme analysis of viral genomic DNA allows comparison of CMLV isolates. The genome of CMLV is completely sequenced as the virus is closest to VARV. Examination of the genome organization of CMLV has revealed a distinct pattern after Hind III digestion. Comparative RE analyses of genomic DNA of five isolates of camels from different geographical regions of Africa and Asia using Hind III and Xho I demonstrated minor differences between them, which is similar to the conclusions drawn for CMLV isolates from Dubai but was contrary to the RE profile of VACV strains(Pfeffer et al., 1995; RennerMuller, 1995).

\subsubsection{Polymarase Chain Reaction}

PCR is a fast and sensitive method for the detection of OPXV DNA. Electron microscopy is a quick and less sensitive technique for pox virus diagnosis. But the disadvantage is that the equipment may not always be available in all laboratories. Virus isolation and identification is a sensitive method, but it is not rapid. Virus isolation in cell culture detects only live virus particles, and therefore particles that have been inactivated during processing of scabs or transportation to the laboratory may not be detected, therefore, many scab specimens are PCR positive but virus isolation negative (Sullivan et al., 1994).

\section{Public Health Significance}

Human cases of Camel pox have been described as rare or inexistent. Indeed, few articles reported individuals with lesions on the arms, or 
ulcers on the lips and in the mouth (from drinking milk of infected animals), but they all remained unconfirmed (Kriz, 1982). However, recently, Camel pox has been described as a possible zoonosis with three human cases identified and laboratory confirmed in India (Bera et al., 2011). These camel handlers, in direct contact with came pox -infected animals, developed skin lesions localized on the fingers and the hands. Identification of CMLV as the causative agent was made (i) based on the detection of Camel pox neutralizing antibodies in serum samples of the three suspected cases, (ii) by amplification of a CMLV specific gene (C18L), and (iii) by further amplification and sequencing of other genes whose sequences were confirmed to match those of CMLV. These findings should be taken into consideration in the actual context of increasing number of OPV infections in humans and animals. However, came pox appears largely restricted to camels, and seldom produces clinical disease in humans. Reports of human came 1 pox cases either confirmed or not by virological tests, have suggested a mild course of disease even though CMLV is genetically more closely related to VARV than to other OPVs (Al Zi'abiet al., 2007).

\section{CAMEL POX STATUS IN ETHIOPIA}

Camel pox is one of the most important infectious diseases of camels in Ethiopia. The disease has been reported from Oromia, Afar, Somali, and Amhara regional states. InEthiopia, a clinical prevalence ranging from $0.45 \%$ to $14.2 \%$ has been reported in different parts of the country (Demeke, 2002; Megerssa, 2010; Ayeletet al., 2013). Most of these studies have reported that the disease commonly affects young immature camels and the incidence is higher during the rainy season. Recently, the national veterinary institute has developed a new attenuated vaccine which provides a protection for a year. Currently, about one million dose of the vaccine is distributed to major camel producing parts of the country including Somali, Borena and Afar (Personal communication).

\section{CONCLUSION AND RECOMMENDATIONS}

Camel pox is an economically important contagious skin disease of camelids caused by Camel pox virus and is characterized by mild local skin infection and less common severe systemic infections. The disease is confined to camel-rearing belts particularly in developing countries like Ethiopia and causes economic impact due to considerable loss in terms of morbidity, mortality, loss of weight and reduction in milk yield. Camel pox virus was earlier thought to be a zoonotic agent but so far little evidence has been documented from Somalia and India. Although the disease can be diagnosed based on clinical signs, the similar confounding skin lesions necessitate identification of infection by molecular biology based diagnostic techniques, like restriction enzyme analysis of the virus genome and specific genes, genus- and species-specific diagnostic PCRs including real-time quantitative PCR, and sequence and phylogenetic analysis for differentiation of Camel pox virus. Both inactivated and live attenuated vaccines are available in some countries. However, live vaccines are preferred as they provide longlasting immunity. Considering the emerging nature of the virus and the economic impact caused in the camel industry and pastoralists, the control and eradication of the disease by routine epidemiological surveillance and sensitive and specific test is of paramount importance. Based on the above conclusion the following recommendations are forwarded:

- Regular Vaccination of camels particularly the young

- To reduce the impact of the disease in endemic areas, community awareness on risk factors is needed.

- Camel herders should be aware about the zoonotic importance of camel pox. Routine epidemiological surveillance of the disease is needed.

- Validating easy, rapid, cheap and accurate diagnostic technique that can be used at field condition is needed.

- Further study on zoonotic aspect of this disease is highly encouraged.

\section{REFERENCES}

[1] Ahmad, S., M. Yaqoob, N. Hashmi, S. Ahmad, M. A. Zaman and Tariq, M., 2010. Economic importance of camel: a unique alternative under crisis. Pakistan Veterinary journal, 30: 191-197.

[2] Al Hendi, A. B, Abuelzein, E. M, Gameel, A. A and Hassanein, M. M., 1994. A slow- spreading mild form of Camel pox infection. Journal of Veterinary Medicine, 41: 71-73.

[3] Al-Ziabi, O., Nishikawa, H. and Meyer, H., 2007. The first outbreak of Camel pox in Syria. Journal of Veterinary Medicine Science, 69: 541543.

[4] Ayelet, G., Jenberie, S., Belay, A., Mohammed, A., Mola, B., Gizaw, Y., Muhie, Y.,Gelaye,E., 
Asmare, K. and Skjerve, E., 2013. The first isolation and molecular characterization of Camel pox virus in Ethiopia, Antiviral Research, 23: 45-52.

[5] Aylward, B., Hennessey, K. A., Zagaria, N., Olive, J. M. and Cochi, S., 2000. When is adisease eradicable? 100 years of lessons learned. Journal of Public Health, 90: 1515-15 20.

[6] Azwai, S. M., Carter, S. D, Woldehiwet, Z. and Wernery, U, 1996. Serology of Ortho pox virus cameli infection in dromedary camel's analysis by ELISA and western blotting, Comp. Immunol. Microbiol. Infectctious disease. 19: 65-78.

[7] Balamurugan, V., Bhanuprakash, V. and Hosamani, M., 2009. A polymerase chain reaction strategy for the diagnosis of camel pox, Journal of Veterinary Diagnostic. Investagation, 21: 231-237.

[8] Bera, B. C., Gnanavel, V. and Barua, S., 2010. Zoonotic Camel pox infections in India. International Conference on Protecting Animal Health, Facilitating Trade in Livestock and Livestock Product IAVMI, India, January 27-29.

[9] Berhanu, A., King, D. S. and Mosier, S., 2009. ST-246 inhibits in vivo pox virus dissemination, virus shedding, and systemic disease manifestation. Antimicrobial Agents Chemotherarpy, 53: 4999-5009.

[10] [Bhanuprakash, V, Balamurugan, V, Hosamani, M, Venkatesan, G and Chauhan, B., 2010. Isolation and characterization of Indian isolates of Camel pox virus, Tropical Animal Health and Production, 42: 1271-1275.

[11] Bray, M. and Babiuk, S., 2011. Camel pox: Target for eradication? Antiviral Research 92: 164-166.

[12] Carter, G. R. and Wise, D. J, 2006. "poxviridae". A Concise Review of Veterinary Virology. Retrieved, 2006-06-10.

[13] Central Statistical Agency, 2008. Federal Democratic Republic of Ethiopia Central Statistical Agency. Agricultural Sample Survey Report on Livestock and Livestock Characteristics, Addis Ababa. Statistical bull., 2:16.

[14] Chauhan. R. S. And Kaushik, R. K., 1987. Isolation of Camel pox virus in India.Depicts the first successful isolation and identification of CMLV in India. Brazillian Veterinary Journal, 143: 581-582.

[15] Coetzer, J. W, 2004. Pox viridae . In: Infectious Diseases of Livestock, Second Edition. In Coetzer JAW, Tustin RC (Eds). Oxford University Press, Southern Africa, 2: 1265-12 67.

[16] Dalling, T.; Robertson, A.; Boddie, G. and Spruell, J, 1988. Diseases of camels. In: The International Encyclopedia of Veterinary Medicine, Edinburgh, U.K.; W. Green and Son.Pp. 585.

[17] Davies, F. G., Mungai, J. N. and Shaw T, 1975. Characteristics of a Kenyan Camel pox virus, Journal of Hygiene, 7: 381-385.

ARC Journal of Animal and Veterinary Sciences
[18] DeClercq, E, 2001. Vaccinia virus inhibitors as a paradigm for the chemotherapy of pox virus infections. Clin Microbiology Review, 14: 382397.

[19] Demeke, A. M, 2002. Study on Mange, pox and Dermatophilosis of camels in Afar and Eastern Amhara Regions, DVM Thesis, Addis Ababa University Faculty of Veterinary Medicine, Debrezeit, Ethiopia.

[20] Duraffour, S., Meyer, H., Andrei, G., and Snoeck, R., 2011. Camel pox virus. Antiviral Research, 92:167-186.

[21] Edwards, G. P. Zeng, B., Saalfeld, W. K., Vaarzon-Morel, P. and McGregor, M, 2008. Managing the Impacts of Feral Camels in Australia: a New Way of Doing Business. Desert Knowledge Cooperative Research Centre (DKCRC), Alice Springs. DKCRC Report 47.

[22] FAO, 2001. Preparation of the first report on the state of the world's animal genetic resources. Guidelines for the preparation of CRs. FAO, Rome

[23] Farah, Z., Eberhard, P., Meyer, J., Rehberger, B., Thomet, A. and Gallman, P. U, 2004. UHTprocessin of camel milk. http://www. dbalp.admin.ch./de/publikationen/docsAccesse d April 27/2013

[24] Fenner, G., Frank, J., Gibbs, E., Paul, J., Frederick, A., Rott, R.., Michael, J.and White, O, 1993. Veterinary Virology (2nd ed.), Academic Press, Inc. ISBN 0-12-253056-X.

[25] Getahun, T. and Bruckner, H, 2000. Camel Milk and Meat Utilization in Eastern Ethiopia, in: proceeding of the Ethiopia Society of Animal Production, August, 2000, Addis Ababa, Ethiopia.

[26] Global livestock production health and Atlas, 2006. Global livestock production and Health atlas of FAO. (http://www.fao.org/ag/glipha/ index.jsp). Accessed April 20/2013.

[27] Grosenbach, D. W, Jordan, R. and King, D. S, 2008. Immune responses to the small pox vaccine given in combination with ST-246, a small-molecule inhibitor of pox virus dissemination. Vaccine, 26: 933-946.

[28] Gubser C, Goodbody, R. and Ecker A, 2007. Camel pox virus encodes a Schlafen-like protein that affects ortho pox virus virulence. Journal General Virology, 88: 1667-1676.

[29] Gubser, C. and Smith, G. L, 2002 .The sequence of Camel pox virus shows it is most closely related tovariola virus, the cause of small pox, Journal of Genenal Virology, 83: 855-872.

[30] Gubser, Caroline, Smith and Geoffrey, 2001. The sequence of Camel pox virus shows it is most closely related to Variola virus, the cause of small pox. Journal of General Virology, 83: 855-872. 
[31] Higgins, A. J., Silvey, R. E., Abdelghafir, A. E. and Kitching, R. P,1992. The epidemiology and control of an outbreak of Camel pox in Bahrain, Proc. 1st. Int. Camel Conf. 101-104.

[32] Hussein, M. F. And Al-Mufarrej, S. L, 1999. Some clinicopathological aspects of Camel pox in Saudi Arabia, J. king. Saud. Univ., Agric. Sci., 11:113-120.

[33] Jezek, Z. Kriz, B. and Rothbaur, V, 1983."Camel pox and its risk to the human population". Journal of Hygiene, Epidemiology, Microbiology, and Immunology, 27: 29-42.

[34] Johann, S. and Czerny, C. P, 1993. A rapid antigen-capture ELISA for the detection of ortho pox viruses. Journal of Veterinary Medicine, 40: 569-581.

[35] Jordan, R., Tien, D. and Bolken, T C, 2008. Singledose safety and pharmacokinetics of ST-246, a novel orthopoxvirus egress inhibitor. Antimicrob Agents Chemotherapy, 52: 1721-17 27.

[36] Khalafalla, A. I. And El Dirdiri, G. A, 2003.Laboratory and field investigations of a live attenuated and an inactivated Camel pox vaccine, Journal of Camel Practical Research, 10: 191-200.

[37] Khalafalla, A. I., Mohamed, M. H. and Ali, B. H, 1998. Camel pox in the Sudan and its isolation and identification of the causative virus, Journal Camel Practical Research, 5: 229-233.

[38] Khalafalla, A. I. and Ali, Y. H, 2007. Observations on risk factors associated with some camel viral diseases. Montpellier, France, pp. 101-105.

[39] Kinne, J., Cooper, J. E. and Wernery, U, 1998. Pathological studies on Camel pox lesions of the respiratory system in the United Arab Emirates (UAE). Journal of Comparative Pathology, 118: 257-266.

[40] Kriz, B, 1982. A study of Camel pox in Somalia. Journal Comparative Pathology, 92:1 - 8.

[41] Marennikova, S. S., Malceva, N. N. and Habahpaseva, N. A, 1981. ELISA - a simple test for detecting and differentiating antibodies to closely related ortho pox viruses. Bullet of World Health Organization, 59: 365-369.

[42] Marodam, V., Nagendrakumar, S. B. and Tanwar, V. K, 2006. Isolation and identification of Camel pox virus. Indian Journal of Animal Science, 76: 326-327.

[43] Mayer, A. and Czern, C. P, 1990. Camel pox Virus. In: Virus Infections of Vertebrates, Virus Infectionsof Ruminants, Dinter Z. and Morein B., eds. Elsevier Science Publisher B.V., Amsterdam, Oxford, New York, Tokyo, 3: 19-22.

[44] Megerssa, B, 2010. An epidemiological study of major camel diseases in the Borana lowland, Southern Ethiopia. DCG Report No. 58.

[45] Meyer, H., Pfeffer, M. and Rziha, H. J, 1994. Sequence alterations within and downstream of the A-type inclusion protein genes allow differentiation of ortho pox virus species by polymerase chain reaction, Journal of General Virology, 75: 1975- 1981.

[46] Mona, A., Mahmoud, R., Abo-Elnag, A. Osman,Ayatollah, I., Bassiouny, M. and Azza S, 2012. Epidemiology and Characterization of Camel pox virus in Northwest Costal Area of Egypt. Global Veterinaria, 9: 738-744.

[47] Munz, E., Kropp, E. and Reimann M. 1986. Demonstration of antibodies against ortho pox viruscameli in sera of East African dromedaries by ELISA, Journal of veterinary medicine, 3: 221-230.

[48] Munz, E., Otterbein, C. K., Meyer, H. and Renner, I., 1997. A laboratory investigation to demonstrate a decreased virulence of two cell cultures adapted African Camel pox virus isolates as possible vaccine candidates, Journal of Camel Practical Research, 4: 169-175.

[49] Murphy, F. A., Gibbs, E. J., Horzinek, M. C. and Studdert, M. J, 1999. Veterinary Virology. 3rd Edition, Academic Press, San Diego, CA, USA, 282.

[50] Nothelfer, H. B., Wernery, U. and Czerny, C. P, 1995. Camel pox: antigen detection within skin lesions - immunohistochemistry as a simple method of etiological diagnosis. Journal of Camel Practical Research, 2: 119-121.

[51] November, F. J., Raska, K. and Holowczak, J. A, 1989. The immune response to vaccinia virus infection in mice: analysis of the role of antibody, Arch. Virology, 107: 273- 289.

[52] OIE, 2008. Manual of Diagnostic Tests and Vaccines for Terrestrial Animals. 6th Edition.

[53] Volume 2, Chapter 2.7.14. OIE, France, 2008.

[54] Pfahler, W. E., Reimann, M. and Munz, E, 1986. A bitoin-avidin amplified enzyme immunoassay for detection and quantitation of orthopoxvirus camel antibodies in dromedaries. Journal of Veterinary Medicine, 33: 477-484.

[55] Pfeffer, M., Meyer, H.,Wernery, U. and Kaaden, O. R, 1996. Comparison of Camel pox viruses isolated in Dubai. Veterinary Microbiology, 49:135-146.

[56] Pfeffer, M., Wernery, U., Kaaden, O. R. and Meyer, H, 1998. Diagnostic procedures for pox virus infections in camelids. Journal of Camel Practical Research, 5: 189- 195.

[57] [Quenelle, D. C., Prichard, M. N. and Keith, K. A., 2007. Synergistic efficacy of the combination of ST-246 with CMX001 against orthopoxviruses, Antimicrobial Agents Chemotherapy, 51: 4118-4124.

[58] Renner-Muller, I. C., Meyer, H. and Munz, E, 1995. Characterization of Camel pox virus isolates from Africa and Asia. Veterinary Microbiology, 45: 371-381. 
[59] Sahay, B, 2006. Evaluation of gene silencing by RNA interference (RNAi) in control of animal virus infections. PhD thesis, Deemed University, IVRI, Izatnagar, India.

[60] Schwartz, H. J. and Dioli, M, 1992. The OneHumped Camel in Eastern Africa. A Pictorial Guide to Diseases, Health care and Management,Weikersheim, Germany, Verlag Josef Margraf Publishers. Pp. 282.

[61] Smee, D. F., Sidwell, R. W., Kefauver, D., Bray. M. and Huggins, J. W, 2002. Characterization of wild-type and cidofovirresistant strains of camel pox, cow pox, monkey pox, and vaccinia viruses. Antimicrobial Agents Chemotherapy, 46: 13291335

[62] Sullivan, J. T., Mercer, A. A., Fleming, S. B. and Robinson, A. J, 1994. Identification and characterization of an orf virus homologue of the vaccinia virus gene encoding the major envelope protein p37. Virology, 202: 471-478. .

[63] United State Agency for international Development, 2005. Multi-Sectoral Interventions in Pastoralist Communities: Horn of Africa, 2005.

[64] Tantawi, H. H., Saban, M. S., Reda, I. M. and El-Dahaby, H, 1974. Camel pox virus in Egypt. Isolation and characterization, Bull. Epizoot. Dis. Africa. 22: 315-319.

[65] Wernery, U., Kaaden, O. R, and Ali, M, 2000. Ortho pox virus infections in dromedary camels in United Arab Emirates (U.A.E.) during winter season. Journal of Camel Practical Research, 4: 51-55.

[66] Wernery, U. and Kaaden, O. R, 2002. Camel pox. In: Infectious Diseases in Camelids,
Second Edition, Wernery U. and Kaaden O.-R., eds. Blackwell Science Berlin, Vienna, 176-185.

[67] Wernery, U, 1995. Viral infections in camels a review. Journal of Camel Practical Research, 2: $1-12$.

[68] Wernery, U., Meyer, H. and Pfeffer, M, 1997. Camel pox in the United Arab Emirates and its prevention. Journal of Camel Practical Research, 4: 135-139.

[69] Wernery, U. and Zachariah, R, 1999. Experimental Camel pox infection in vaccinated and unvaccinated dromedaries. Journal of Veterinary Medicine, 46: 131-135.

[70] Wilson, R. T., Araya, A. and Melaku, A, 1990. The One-Humped Camel. Technical Papers Series No. 3. New York, UNSO. Pp: 300.

[71] Wilson, R. T, 1998. The camel, Longman, London and New York, Pp: 60-65.

[72] Yager, J. A., Scott, D. W. and Wilcock, B. P, 1991. Viral diseases of the skin. In: Pathology of Domestic Animals, Fourth Edition, Jubb K. F., Kennedy P.C. and Palmer N., eds. Academic Press, San Diego, USA, 629-644.

[73] Yang, G., Pevear, D. C. and Davies M. H, 2005. An orally bioavailable anti pox virus compound (ST-246) inhibits extracellular virus formation and protects mice from lethal ortho pox virus Challenge. Journal of Virology, 79: 13139-13149.

[74] Xiong. X., Smith, J. L., Kim, C., Huang, E. and Chen, M. S, 1996. Kinetic analysis of the interaction of cidofovirdiphosphate with human cytomegalovirus DNA polymerase, Biochemistry and Pharmacology, 51: 1563-15 67.

Citation: Diriba Achalu Bayisa, Review on Camel Pox: Epidemiology, Public Health and Diagnosis. ARC Journal of Animal and Veterinary Sciences. 2019; 5(4):22-33. doi: dx.doi.org/10.20431/2455-2518.0504003.

Copyright: (C) 2019 Authors. This is an open-access article distributed under the terms of the Creative Commons Attribution License, which permits unrestricted use, distribution, and reproduction in any medium, provided the original author and source are credited. 